\title{
Compaction and soil disturbances from logging in Southern Chile
}

\author{
J Gayoso *, A Iroumé \\ Instituto de Manejo Forestal, Universidad Austral de Chile, Casilla 853, Valdivia, Chile
}

(Received 2 July 1990; accepted le 13 november 1990)

\begin{abstract}
Summary - In an andesitic dystrochrept clay forest soil, the effect of a different number of passes of a rubber-tyred skidder on bulk density, total porosity and saturated hydraulic conductivity was studied. Soil samples were taken in undisturbed areas, and under skid trails with 1, 2, 3, 5 and 10 machine passes. Most compaction occurred after the initial few passes, but bulk density also increased significantly after more than 3 passes. Increases in bulk density were still important at the maximum sampling depth of $20 \mathrm{~cm}$. Total porosity decreased for all treatments, associated with a reduction of macropores. The saturated hydraulic conductivity became significantly reduced after the first initial passes. The effect of compaction on tree growth needs to be further studied and quantified.
\end{abstract}

soil compaction / soil disturbances / ground-based logging / bulk density / saturated hydraulic conductivity

Résumé - Compactage et perturbation du sol après une exploitation forestière au Chili méridional. On a étudié l'influence du nombre de passages d'un débusqueur à pneus sur la densité apparente, la porosité totale et le coefficient de conductivité hydraulique d'un sol brun andésitique. Des échantillons de sol ont été prélevés dans des terrains non perturbés, et sous des chemins de débardage ayant 1,2, 3, 5 et 10 passages. Le compactage le plus important s'est produit après les premiers passages, mais la densité apparente a encore augmenté significativement après le troisième passage. La densité apparente a aussi augmenté jusqu'à $20 \mathrm{~cm}$ de profondeur. La porosité totale a été réduite dans tous les cas, associée à une réduction des macropores. Le coefficient de conductivité hydraulique a été significativement réduit après les premiers passages. L'effet du compactage du sol sur la croissance des arbres doit être étudié et quantifié.

compactage du sol / perturbation du sol / débusqueur à pneus / densité apparente / coefficient de conductivité hydraulique

\section{INTRODUCTION}

In Chile, forestry-related activities have increased substantially during the last $15 \mathrm{yr}$. This is partly due to the growth of the area under plantations at an average of 79000 ha $\mathrm{yr}$ since 1973, reaching more than
1240000 ha in 1986 (Instituto Forestal, 1987). Increased mechanization and the use of heavy machinery in logging operations have caused severe disturbances to forest soils, and compaction effects have been widely reported within the country (Monrroy, 1981; Gayoso, 1982; Gayoso and Iroumé; 1984).

* Correspondence and reprints 
According to Beekman (1987) compaction alters the soil's physical and mechanical properties and leads to a less favorable condition for plant growth, which in turn leads to a decline in site productivity (Gessel, 1981) and reduces the present net worth of future timber harvests (Routledge, 1987).

Compaction can extend to a considerable depth of the soil profile (Moehring, 1970) and the major compaction occurs during the first passes of machinery (Adams and Froehlich, 1981). Upon compaction, soil strength increases while total porosity, available water, air content, infiltration rate and saturated hydraulic conductivity decrease (Incerti et al, 1987). As a consequence, tree growth can be reduced because of restrictions in root development, water supply and aeration (Corns, 1988; Vepraskas, 1988). In addition, surface runoff may increase and soil erosion be promoted (Sidle, 1980; Standish et al, 1988).

The extension of soil disturbances can be reduced by designing skid trails prior to harvesting (Froehlich et al, 1981). The intensity can be reduced by harvesting during the driest periods of the year, logging downhill where possible and selecting low ground pressure equipment (Wingate-Hill and Jakobsen, 1982). Sometimes damaged soils can be ameliorated by cultivation (Moehring, 1970).

Chilean foresters have become aware of soil alterations, but the degree and extent of the problem has not been widely quantified. The objective of this study was to assess compaction intensity and the effects on soil dry bulk density, total porosity and saturated hydraulic conductivity, following a clearcutting operation in southern Chile.

\section{THE STUDY AREA}

The study area is located a approximately $39^{\circ} 44^{\prime} \mathrm{S}$ and $73^{\circ} 10^{\prime} \mathrm{W}, 15 \mathrm{~km}$ from the city of Valdivia in southern Chile. The site has a northern aspect with slopes varying between $5 \%$ and more than $60 \%$, and elevations ranging from 110 to $220 \mathrm{~m}$ above sea level.

The area was covered with a 25 -yr-old Monterey pine plantation clear-felled during the last winter. A rubber-tired skidder was used to transport uphill logs to landings.

The climate of the area is rainytemperate with a Mediterranean influence (Fuenzalida, 1965). Annual rainfall in the city of Valdivia ( $9 \mathrm{~m}$ above sea level) ranges from 1752 to more than $2936 \mathrm{~mm}$ (Fuenzalida, 1965). The period between May and August concentrates $70 \%$ of the $2340 \mathrm{~mm}$ long-term annual average rainfall (Reyes, 1981). Mean annual temperature is $12{ }^{\circ} \mathrm{C}$ with a maximum monthly mean of $16.9^{\circ} \mathrm{C}$ in January, and a minimum of $7.6^{\circ} \mathrm{C}$ in July. Predominant winds come from the north between April and September, and from the west between October and February.

The geological substratum corresponds to the "Piedra-Laja" formation, a coastal metamorphic complex formed mainly by micaceous schists with intercalations of quartz lenses (lllies, 1970).

Soils correspond to an andesitic dystrochrept forest type (Série Correltue) developed from pleistocene volcanic ash deposited on the coastal metamorphic complex (Gayoso and Iroumé, 1984). Apart from the high clay content (40-50\%), they have a high porosity and high water 
infiltration rate. Table I presents some of the soil's physical and chemical properties.

\section{METHODS}

Within the logging site, sampling plots were selected in undisturbed and disturbed areas. In this study, areas not used as trails or log landings were considered as undisturbed. In disturbed areas with a 10 and $20 \%$ slope, plots were chosen under skid trails with 1,2, 3, 5 and 10 machine passes. In areas with a $10 \%$ slope, the logged volumes in each pass were 2 and 4 cubic meters ( 3 and 6 logs respectively), while in areas with a $20 \%$ slope the logged volume was $2 \mathrm{~m}^{3}$ ( 3 logs). The skidder used to log uphill whole trees was a rubber-tyred Caterpillar 518 with the following characteristics: weight: 10250 $\mathrm{kg}$; tyre sizes: $18.4 \times 30 "$, tyre pressure: 170 $\mathrm{kPa}$.

In the top $5 \mathrm{~cm}$ of the soil profile of each plot, 9 undisturbed core samples of $100 \mathrm{~cm}^{3}$ were collected. In addition, 3 samples of $100 \mathrm{~cm}^{3}$ were taken from each of the following depths in the soil profile: 6 to 10,11 to 15 , and 16 to 20 $\mathrm{cm}$. The soil samples were oven-dried at $105^{\circ} \mathrm{C}$

Table I. Selected top soil physical and chemical properties.

\begin{tabular}{lc}
\hline \multicolumn{1}{c}{ Property } & Value \\
\hline Bulk density $\left({\left.\mathrm{Mg} \cdot \mathrm{m}^{-3}\right)}^{-3}\right)$ & 0.62 \\
Particle density $\left(\mathrm{Mg}^{-3}\right)$ & 2.50 \\
Total porosity $(\%)$ & 75 \\
Porosity < 0.2 $\mu \mathrm{m}(\%)$ & 31 \\
Sand $(\%)$ & 30 \\
Silt $(\%)$ & 26 \\
Clay $(\%)$ & 44 \\
Aggregate average size & \\
dry-sieved (mm) & 1.7 \\
wet-sieved (mm) & 1.2 \\
Plastic limit (\%) & 50 \\
Liquid limit (\%) & 71 \\
Cohesion (kPa) & 71 \\
Internal friction angle ( $\left.{ }^{\circ}\right)$ & 4 \\
Total carbon (\%) & 7.45 \\
\hline
\end{tabular}

for $24 \mathrm{~h}$ to obtain dry bulk density and total porosity (Lee et al, 1983).

From the top $12 \mathrm{~cm}$ of the soil profile, 6 undisturbed core samples of $940 \mathrm{~cm}^{3}$ were also collected in each plot. The samples were saturated and the saturated hydraulic conductivity was measured using a constant head permeameter, according to Head (1982).

All intact core samples were collected using a double-cylinder hammer-driven core sampler, and all sample points were randomly selected. Traffic and sampling occurred during the wet period. Soil water content in undisturbed areas was $84 \%$ in surface (0-10 cm deep) and $66 \%$ in the 11-20 cm deep layer.

\section{RESULTS AND DISCUSSION}

In areas with a $10 \%$ slope, the differences between the results of soil alterations under trails where the skidder snig logged 2 and $4 \mathrm{~m}^{3}$, respectively, were statistically non significant, and are presented as belonging to the same data population.

\section{Bulk density and total porosity}

The results in figure 1 show that in areas with a $10 \%$ slope, the bulk density in the top $5 \mathrm{~cm}$ of the soil increased by $11 \%$ after 1 pass, $15 \%$ after 2 passes, $21 \%$ after 3 turns, $31 \%$ after 5 machine passes, and $45 \%$ under trails with 10 skid passes. Bulk density also increased in depth under the skid trails. For example, in areas with a $10 \%$ slope, the bulk density increased by $39 \%$ between 6 to $10 \mathrm{~cm}$ depth, by $34 \%$ between 11 to $15 \mathrm{~cm}$, and by $32 \%$ between 16 to $20 \mathrm{~cm}$, after 10 machine passes.

In areas with a $20 \%$ slope, the bulk density in the top $5 \mathrm{~cm}$ of the soil increased by $23 \%$ after 1 pass, $32 \%$ after 2 machine passes, $37 \%$ after 3 turns, $48 \%$ after 5 passes, and $60 \%$ under trails with 10 skid passes (fig 2). As occurred in areas with a 


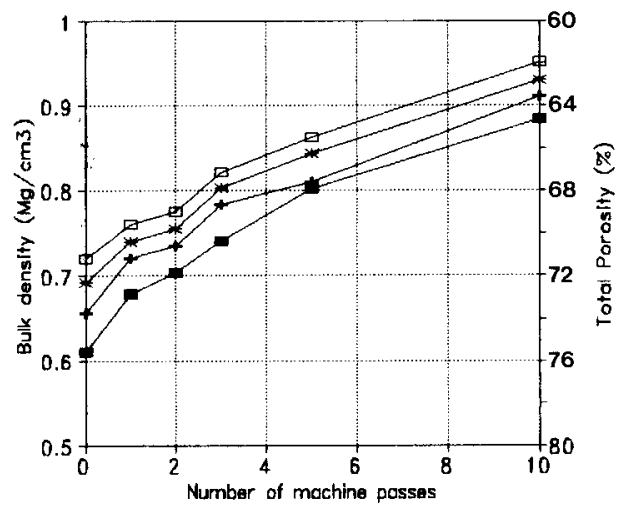

Fig 1. Effect of skid passes on soil bulk density (10\% slope).

0-5 cm;

$10 \%$ slope, bulk density also increased in depth under the skid trails with a $20 \%$ slope. After 10 machine passes, the bulk density increased by $52 \%$ between 6 to 10 $\mathrm{cm}$ depth, $46 \%$ between 11 to $15 \mathrm{~cm}$, and $43 \%$ between 16 to $20 \mathrm{~cm}$.

These increases differ from those presented by Adams and Froehlich (1981) and Incerti et al (1987) but can be explained by different soil types and conditions, and logging equipment. Moehring and Rawls (1970) found that more severe compaction occurs from traffic on saturated than on dry soils.

In trails with a $20 \%$ slope, the increase in bulk density for all different numbers of machine passes and depths was significantly higher as compared with those observed in trails with a $10 \%$ slope. This may be a consequence of the difficulties that the skidder found when logging in steep terrains. Under these conditions the machine slipped continuously and remained for a longer period of time in a given place, puddling and dragging the soil.

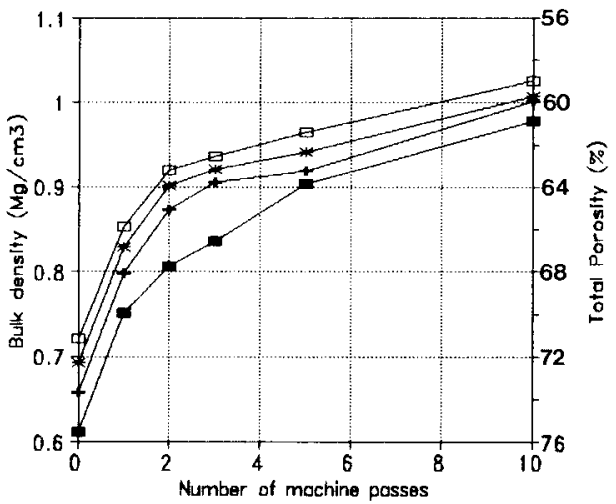

Fig 2. Effect of skid passes on soil bulk density (20\% slope).

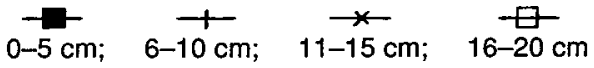

From figures 1 and 2 it can be seen that most compaction occurred after the first few passes, although bulk density still increased significantly after more than 3 passes for all layers. This is slightly different from data presented by Froehlich (1978) and Adams and Froehlich (1981).

From data obtained in a clay loam soil in the Oregon coast range, Sidle and Drlica (1981) developed a regression equation to determine the impact of the number of passes and slope gradient on bulk density. These authors found that the slope did not significantly affect bulk density, but they concluded that it can be an important factor in the potential level of compaction.

This fact was proven in this study, and the best relationship between bulk density $\left(B D\right.$ in $\mathrm{Mg} \mathrm{m}^{-3}$ ) as dependent variable, and number of machine passes (NP) and slope gradient ( $S G$ in \%) as independent variables, for all 4 depths, were :

(for $0-5 \mathrm{~cm}$ ) $B D=0.56+0.22 \log _{10}$

$(N P)+0.009 S G\left(r^{2}=0.977\right)$ 
(for $6-10 \mathrm{~cm}$ ) $B D=0.59+0.19 \log _{10}$ $(N P)+0.011 S G\left(r^{2}=0.965\right)$

(for $11-15 \mathrm{~cm}$ ) $B D=0.62+0.18 \log _{10}$ $(N P)+0.011 S G\left(r^{2}=0.969\right)$

(for $16-20 \mathrm{~cm}$ ) $B D=0.64+0.18 \log _{10}$ $(N P)+0.011 S G\left(r^{2}=0.970\right)$

The coefficients of determination for all equations were significant at the $\alpha=0.01$ level and the standard errors of $B D$ estima-

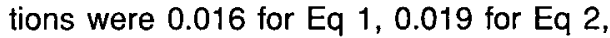
0.017 for Eq 3 and 0.017 for Eq 4 .

A value of $1.10 \mathrm{Mg} \cdot \mathrm{m}^{-3}$ for bulk density on the top soil layer has been measured in the same area under logging roads and landings (Gayoso and Iroumé, 1984). Although it is hazardous to use Eq 1 to extrapolate beyond 10 passes, it is possible to estimate that such bulk density is reached after 50 or 100 machine passes, depending on the slope gradient.

Close to the studied area, growth losses of up to $30 \%$ in tree height have been reported associated with severe compaction and bulk densities of $1.07 \mathrm{Mg} \cdot \mathrm{m}^{-3}$ (Gayoso, 1982). According to Sidle and Drlica (1981), bulk density in trails with 4 to 11 passes can be considered as intermediate compaction, and this level of compaction can affect site productivity. The limit of bulk density from which compaction can reduce non-capillary porosity and root development to critical levels for tree growth must be determined for each individual soil type.

As can be observed from these results, in all cases the major increases occurred in the top of the soil profile but they were still important at $16-20 \mathrm{~cm}$, suggesting that compaction extended deeper. According to this observation, compaction could affect the top $30-40 \mathrm{~cm}$ of the soil where a greater part of the root system of Monterey pine is distributed (Murphy, 1982).

Bulk density can recover, especially in surface layers. Hatchell et al (1970) estimated by regressions that recovery to un- disturbed conditions can be expected $18 \mathrm{yr}$ after compaction. However, Went and Thomas (1981) reported that compaction was still severe after 32 yr. Severely compacted soils could be retored by ploughing, disking and subsoiling.

Due to the existence of the one-to-one correspondence between bulk density and percentage total porosity, total porosity decreased after a different number of machine passes associated with increases in bulk density (figs 1 and 2).

The decrease in total porosity for all treatments must be associated with a reduction of macropores. For this soil, Gayoso and Ellies (1984) determined that macropores (ie $>50 \mu \mathrm{m}$ ) decreased from 28.1 to $9.2 \%$, that the percentage of intermediate porosity (ie 0.2 to $50 \mu \mathrm{m}$ ) remained almost invariable, and that micropres (ie $<0.2 \mu \mathrm{m}$ ) increased from 30.5 to $40.4 \%$, from undisturbed to severely compacted conditions.

According to Baver et al (1972), a reduction of macropores below $10 \%$ of soil volume at matric potentials below $100 \mathrm{~cm}$ water can be considered to be restrictive to root growth because of poor aeration and increase in soil strength. Jurgensen et al (1979) found that major productivity losses are associated with poor oxygen availability.

The decrease in total porosity is not a clear indication of restrictions to root and tree growth, and it is certainly not critical for Monterey pine establishment; at least in a soil such as the one studied that has $75 \%$ total porosity. The determination of pore size distribution is essential for future studies.

\section{Saturated hydraulic conductivity}

The results for the saturated hydraulic conductivity $(K)$ of the top $12 \mathrm{~cm}$ of the soil are 
presented in table II. According to Rogowsky (1972), Talsma and Hallam (1980) and Incerti et al (1987) it is possible to assume a log-normal distribution for the data of eachi individual treatment. The geometric mean can then be calculated because it equals the median value for a lognormal distribution, and the antilog of the standard deviation of the transformed data may be used as an index of variability.

Associated with an increase of bulk density and a decrease in total porosity, the saturated hydraulic conductivity varied for all treatments. In areas with a 10\% slope, the geometric mean value for $K$ decreased by $35 \%$ after 1 pass, $89 \%$ after 2 machine passes, $90 \%$ after 3 machine passes, $93 \%$ after 5 passes, and $99 \%$ under trails with 10 skid passes. In areas with a $20 \%$ slope, $K$ decreased by $90 \%$ after 1 pass, $94 \%$ after 2 machine passes, 97\% after 3 passes, $98 \%$ after 5 passes, and $99 \%$ under trails with 10 skid passes.

In spite of the variations of 1-2 orders of magnitude of $K$, the higher values of anti$\log S$ were not much greater than 2 , and for some of the individual treatments even smaller than 2 . This value (2) for the index of variability has been tentatively suggested by Rogowsky (1972) as an upper limit for uniformity of hydraulic conductivity within soil series. The values obtained in this study for such an index suggest that $K$ was relatively uniform.

According to Incerti et al (1987) the median and the range for each treatment can indicate the difference between treatments. In the skid trails with a 10 and $20 \%$

Table II. Saturated hydraulic conductivity.

\begin{tabular}{|c|c|c|c|c|c|c|c|}
\hline \multirow{2}{*}{$\begin{array}{l}\text { No of } \\
\text { machine } \\
\text { passes }\end{array}$} & \multirow{2}{*}{$\begin{array}{l}\text { Total } \\
\text { porosity } \\
\text { (\%) }\end{array}$} & \multirow{2}{*}{$\begin{array}{c}\text { Slope } \\
\text { gradient } \\
(\%)\end{array}$} & \multicolumn{4}{|c|}{$\begin{array}{l}\text { Saturated hydraulic conductivity } \\
\qquad(m \cdot d a y-1)\end{array}$} & \multirow{2}{*}{$\begin{array}{l}\text { Variability } \\
\text { (antilog S) }\end{array}$} \\
\hline & & & Mean & $\begin{array}{l}\text { Geometric } \\
\text { mean }\end{array}$ & Median & Range & \\
\hline$u\left({ }^{*}\right)$ & 74.8 & & 3.737 & 2.078 & 3.586 & $0.13-8.55$ & 4.04 \\
\hline 1 & $\begin{array}{l}72.8 \\
70.5\end{array}$ & $\begin{array}{l}10 \\
20\end{array}$ & $\begin{array}{l}2.944 \\
0.330\end{array}$ & $\begin{array}{l}1.359 \\
0.218\end{array}$ & $\begin{array}{l}2.652 \\
0.302\end{array}$ & $\begin{array}{l}7.7710^{-2}-8.04 \\
5.3610^{-2}-0.80\end{array}$ & $\begin{array}{l}4.75 \\
2.75\end{array}$ \\
\hline 2 & $\begin{array}{l}72.4 \\
69.2\end{array}$ & $\begin{array}{l}10 \\
20\end{array}$ & $\begin{array}{l}0.335 \\
0.210\end{array}$ & $\begin{array}{l}0.230 \\
0.120\end{array}$ & $\begin{array}{l}0.246 \\
0.127\end{array}$ & $\begin{array}{l}7.1710^{-2}-0.95 \\
2.7310^{-2}-0.74\end{array}$ & $\begin{array}{l}2.14 \\
2.85\end{array}$ \\
\hline 3 & $\begin{array}{l}71.1 \\
68.0\end{array}$ & $\begin{array}{l}10 \\
20\end{array}$ & $\begin{array}{l}0.302 \\
0.067\end{array}$ & $\begin{array}{l}0.216 \\
0.054\end{array}$ & $\begin{array}{l}0.205 \\
0.055\end{array}$ & $\begin{array}{l}6.8210^{-2}-0.68 \\
2.5910^{-2}-0.16\end{array}$ & $\begin{array}{l}2.81 \\
1.88\end{array}$ \\
\hline 5 & $\begin{array}{l}64.4 \\
62.7\end{array}$ & $\begin{array}{l}10 \\
20\end{array}$ & $\begin{array}{l}0.171 \\
0.060\end{array}$ & $\begin{array}{l}0.140 \\
0.050\end{array}$ & $\begin{array}{l}0.113 \\
0.048\end{array}$ & $\begin{array}{l}5.0910^{-2}-0.37 \\
2.5910^{-2}-0.14\end{array}$ & $\begin{array}{l}1.86 \\
1.86\end{array}$ \\
\hline 10 & $\begin{array}{l}61.7 \\
56.9\end{array}$ & $\begin{array}{l}10 \\
20\end{array}$ & $\begin{array}{l}0.034 \\
0.035\end{array}$ & $\begin{array}{l}0.023 \\
0.018\end{array}$ & $\begin{array}{l}0.035 \\
0.017\end{array}$ & $\begin{array}{l}4.3210^{-2}-0.16 \\
8.6410^{-3}-5.9610^{-2}\end{array}$ & $\begin{array}{l}2.89 \\
2.28\end{array}$ \\
\hline
\end{tabular}

(*) $\mathrm{u}=\mathrm{undisturbed}$ areas 
slope, the median and also the mean, geometric mean and the range decreased with increases in the number of machine passes.

The decrease in hydraulic conductivity is related to a decrease in total porosity. The best relationship found between the geometric mean of $K$ (in m•day ${ }^{-1}$ ) and total porosity (TP in \%) obtained from the top 12 $\mathrm{cm}$ soil samples is :

$$
\begin{aligned}
& \log _{10} K=-29.14+15.47 \log _{10} T P \\
& \left(r^{2}=0.760\right)
\end{aligned}
$$

The coefficient of determination of Eq 5 is significant at the $\alpha=0.01$ level.

The saturated hydraulic conductivity decreased by $90 \%$ (ie from 2.078 to 0.216 $m \cdot d^{-1} y^{-1}$ ) with a decrease in total porosity of only $5 \%$ (ie from 75 to $71 \%$ ). This last value of total porosity was achieved after 1 to 3 passes. A further decrease in $K$ by

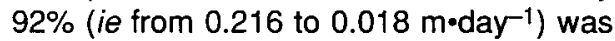
associated with an additional decrease in total porosity of $20 \%$ (ie from 71 to $57 \%$ ). This may be a consequence of a strong reduction of macropores during the first levels of compaction (after 1 to 3 machine passes). After the initial passes, the reduction of total porosity may be caused by a decrease of pores of all sizes, which results in a slower reduction of $K$.

Although saturated hydraulic conductivity is not the only factor that determines surface runoff, in a first approach it can be said that runoff will occur when the rainfall rate exceeds $K$. From rainfall data for the studied area, rainfall events with a recurrence interval of $20 \mathrm{yr}$ can be estimated at $0.15 \mathrm{~m} \cdot \mathrm{d}^{-1}$, and the soil is able to allow the infiltration of such events in areas with less than 2 to 5 skid passes. Because hydraulic conductivity determined in situ can be an order of magnitude smaller than results measured from core samples (Topp and Binns, 1976), runoff may occur more often than predicted.
As occurs with bulk density, the saturated hydraulic conductivity can also recover. Perry (1964) estimated that approximately $40 \mathrm{yr}$ are required to recover the initial infiltration capacity. Considering that the usual rotation period for Monterey pine plantations in Chile is about $25 \mathrm{yr}$, the recovery of $K$ could be restricted.

The decrease in saturated hydraulic conductivity should result in increased runoff, which could promote erosion and nutrient losses while reducing soil water availability. These effects are now being evaluated in experimental sampling plots.

\section{CONCLUSION}

The results show that logging operations at the studied site have a significant impact on the soil's physical properties. Increases in bulk density and decreases in total porosity and saturated hydraulic conductivity were detected. Most compaction occurred after the first few machine passes, although bulk density increased significantly after more than 3 passes. Increases were still important at $20 \mathrm{~cm}$ depth suggesting that compaction could affect the top $40 \mathrm{~cm}$ of the soil, where a greater part of the root system of Monterey pine is located. Further work in this area should at least consider the top $40 \mathrm{~cm}$ of the soil profile and determine critical values of bulk density above which tree growth can be affected. In addition, the effect of high organic matter content on soil compaction resistance under humid conditions must be quantified.

The observed decrease in total porosity must mainly be associated with a reduction in macroporosity, shown by the decrease of hydraulic conductivity. This suggests that poor oxygen availability can be the primary limiting factor to tree growth. Pore size distribution analysis is essential for future studies. 
Saturated hydraulic conductivity was found to be markedly reduced with relatively low decreases in total porosity, resulting in an increased potential for runoff, erosion and nutrient losses, which can further affect site productivity.

In Chile, large areas of man-made forests are intensely managed. Increasing mechanization and the use of heavy machinery in forest operations suggests the need to quantify the extension and intensity of soil compaction, and the effect on tree growth. The natural rate of recovery and the effect of some cultivation practices must also be analyzed.

\section{ACKNOWLEDGMENT}

This work was supported by Proyecto Fondecyt 0916-88.

\section{REFERENCES}

Adams PW, Froehlich HA (1981) Compaction of Forest Soils. USDA Pacific Northwest Ext Pub PNW 217, $13 p$

Baver LD, Gardner WH, Gardner WR (1972) Soil Physics. Wiley, New York, 4th edn

Beekman F (1987) Soil strength and forest operations. Doctoral thesis, Dept For Technique, Agricultural University, Wageningen, The Netherlands, $168 p$

Corns IG (1988) Compaction by forestry equipment and effects on coniferous seedlings growth on four soils in the Alberta foothills. Can J For Res 18, 75-84

Froehlich $H$ (1978) Soil compaction from low ground-pressure, torsion-suspension logging vehicles on three forest soils. Res Pap 36, Oregon State University, $12 p$

Froehlich H, Aulerich D, Curtis R (1981) Designing skid trail system to reduce soil impacts from tractive logging machines. For Res Lab, Oregon State University, Res Pap 44, 15 p
Fuenzalida H (1965) Clima. In: Geografía Económica de Chile. CORFO, Santiago, Chile, 99-151

Gayoso J (1982) Pérdida de la productividad del sitio por efecto del madereo. Actas Reunión de Trabajo sobre Evaluación de la Productividad de Sitios Forestales, 22-24 April 1982, Valdivia, 284-299

Gayoso J, Ellies A (1984) Vorbelastung und Verformung als Folge unterschiedlicher Bewirtschaftung von einigen Böden Südchiles. $Z$ Kulturtechnik Flurbereinigung 25, 39-46

Gayoso J, Iroumé A (1984) Soil disturbance from logging in Southern Chile. In: Proc Symp Effects of Forest Land Use on Erosion and Slope Stability. Environment and Policy Institute, East-West Center, University of Hawai, Honolulu, 203-209

Gessel S (1981) Impacts of modern forestry on continuing forest productivity. Proc XVII IUFRO World Congress, Japan, 3-19

Hatchell GE, Ralston GW, Foil RR (1970) Soil disturbance in logging. $J$ For $68,772-775$

Head KH (1982) Manual of Soil Laboratory Testing. Pentech, London, $123 \mathrm{p}$

Illies H (1970) Geologia de los Alrededores de Valdivia $y$ Volcanismo y Tectónica en Márgenes del Pacífico en Chile Meridional. Universidad Austral de Chile, Valdivia, $64 \mathrm{p}$

Incerti M, Clinnick PF, Willatt ST (1987) Changes in the physical properties of a forest soil following logging. Aust For Res 17, 91-98

Instituto Forestal (1987) Estadísticas Forestales 1986. CORFO, Boletín 1, $100 p$

Jurgensen M, Larsen M, Harvey A (1979) Forest Soil Biology-Timber Harvesting Relationships: A Perspective. USDA For Service Gral Tech Rep INT-69, $12 p$

Lee IK, White W, Ingles OG (1983) Geotechnical Engineering. Pitman, Boston, $508 \mathrm{p}$

Moehring DH (1970) Forest soil improvement through cultivation. J For $68,328-331$

Moehring D, Rawls IW (1970) Detrimental effects of wet weather logging. $J$ For $68,166-$ 167

Monrroy M (1981) Cambios físico-mecánicos de los suelos de textura fina por efecto de madereo con tracción animal y mecanizada. Te- 
sis Ing For Universidad Austral de Chile, Valdivia, $126 \mathrm{p}$

Murphy $G$ (1982) Soil damage associated with production thinning. $N Z J$ For Sci 12, 281292

Perry TO (1964) Soil compaction and Loblolly pine growth. USDA For Sevr Tree Planters Notes 69, 9

Reyes JC (1981) Características de las precipitaciones de Valdivia: 1960-1976. Tésis Universidad Austral de Chile, Valdivia, $48 \mathrm{p}$

Rogowsky AS (1972) Watershed physics: soil variability criteria. Water Res 8, 1015-1020

Routledge RD (1987) The impact of soil degradation on the expected present net worth of future timber harvests. For Sci 33, 823-834

Sidle RC (1980) Impacts of Forest Practices on Surface Erosion. Pacific Northwest Extension Publ PNW 195, $15 p$

Sidle R, Drlica D (1981) Soil compaction from logging with a low-ground pressure skidder in the Oregon Coast ranges. Soil Sci Soc Am J $45,1219-1224$
Standish JT, Commandeur PR, Smith RB (1988) Impacts of Forest Harvesting on Physical Properties of Soils with Reference to Increased Biomass Recovery - A Review. Inf Rep BC-X-301 Pacific Forestry Centre, $24 p$

Talsma T, Hallam PM (1980) Hydraulic conductivity measurements of forest catchments. Aust J Soil Res 30, 139-148

Topp GC, Binns MR (1976) Field measurement of hydraulic conductivity with a modified airentry permeameter. Can J Soil Sci 56, 139 147

Vepraskas MJ (1988) Bulk density values diagnostic of restricted root growth in coarsetextured soils. Soil Sci Soc Am J 52(4), 1117 1121

Went S, Thomas BR (1981) Effects of skid roads on diameter, height and volume growth in Douglas fir. Soil Sci Soc Am J 45, 629-632

Wingate-Hill R, Jakobsen B (1982) Increased mechanisation and soil damage in forests - a review. NZ J For Sci 12 (2), 380-393 